\title{
Caveolin-1 Expression in Odontogenic Cysts and Ameloblastomas
}

\section{Ameloblastom ve Odontojenik Kistlerde Caveolin-1 Ekspresyonu}

\author{
Zohreh JAAFARI-ASHKAVANDI, Soheil PARDIS, Maryam ASADZADEH, Azadeh ANDISHEH-TADBIR, \\ Ali DEHGHANI-NAZHVANI
}

Department of Oral and Maxillofacial Pathology, School of Dentistry, Shiraz University of Medical Sciences, SHIRAZ, IRAN

\begin{abstract}
Objective: The aim of this study is to evaluate the caveolin-1 expression in a group of odontogenic cysts and tumors.

Material and Method: In this cross-sectional study, the expression of caveolin-1 was evaluated immunohistochemically in 75 samples including 18 cases of dentigerous cyst, 18 odontogenic keratocysts, 3 orthokeratinized odontogenic cysts, 2 calcifying odontogenic cysts and 34 ameloblastomas (solid and unicystic).

Results: Positive immunohistochemical reaction was found in $100 \%$ of odontogenic cysts and this was significantly more than both unicystic (65\%) and solid (55\%) ameloblastomas.

Conclusion: The present study showed the expression of caveolin-1 in all odontogenic cysts and more than ameloblastomas. The results suggested that absence of caveolin-1 might enhance aggressiveness of odontogenic lesions and could be a useful marker for distinguishing ameloblastomas from other odontogenic lesions.
\end{abstract}

Key Words: Ameloblastoma, Odontogenic cyst, Caveolin-1, Immunohistochemistry

\section{INTRODUCTION}

Odontogenic cysts and tumors originate from remnants of odontogenic epithelium and have a wide spectrum of histopathologic and clinical characteristics, ranging from benign non-invasive to locally invasive or malignant lesions. Histopathologic similarities between these lesions may challenge the correct diagnosis, especially in small size specimens, and may also lead to unnecessary broad surgery (1- 5). Recently, immunohistochemistry (IHC) has been employed to differentiate various lesions or predict their biologic behavior by using proper markers (6). For example, some cytokeratins have been investigated and found to be suitable for differentiating odontogenic keratocysts from other odontogenic cysts (7). It is also stated that calretinin is

(Turk Patoloji Derg 2014, 30:94-99)

Received : 10.01.2014 Accepted : 04.02.2014

\section{ÖZ}

Amaç: Bu çalışmanın amacı, bir grup odontojenik kist ve tümörde caveolin-1 ekspresyonunu değerlendirmektir.

Gereç ve Yöntem: Bu çalışmada, caveolin-1 ekspresyonu, 18 dentigeröz kist, 18 odontojenik keratosit, 3 ortokeratinize odontojenik kist, 2 kalsifiye odontojenik kist ve 34 ameloblastomu (solid ve unikistik) içeren 75 olguda immünohistokimyasal olarak değerlendirilmiştir.

Bulgular: Odontojenik kistlerin \% 100'ünde pozitif immünohistokimyasal reaksiyon saptanmıştır. Bu sonuç hem unikistik (\% 65) hem de solid (\% 55) ameloblastomada saptanandan anlamlı ölçüde yüksektir.

Sonuç: Bu çalışma caveolin-1 ekspresyonunun, bütün odontojenik kistlerde ameloblastomalardan daha fazla olduğunu göstermiştir. Bulgular caveolin-1 yokluğunun odontojenik lezyonların agresivitesini arttırabileceğini ve ameloblastomaların diğer odontojenik lezyonlardan ayırt edilebilmesi için yararlı bir gösterge olabileceğini ortaya koymuştur.

Anahtar Sözcükler: Ameloblastoma, Odontojenik kist, Caveolin-1, İmmünohistokimya

a marker for stellate reticulum-like cells of ameloblastoma and can be used to distinguish this tumor from other odontogenic tumors (8).

Caveolin-1 (cav-1) is the main protein that participates in formation of caveolae that are 50-100 nm omega-shaped invaginations of the plasma membrane (9). Caveolae are primarily formed by caveolin proteins including cav- 1,2 , and 3 that are expressed in various mammalian cells. They have a loop structure with common topology: Cytoplasmic $\mathrm{N}$-terminus with scaffolding domain, cytoplasmic C-terminus, and a long transmembrane domain (10). They can move into the cytoplasm and return to the cell surface (11). In 1992, the first protein marker from this family was produced and named caveolin/vip21 which is now

Correspondence: Zohreh JAAFARI-ASHKAVANDI

Department of Oral and Maxillofacial Pathology, School of Dentistry,

Shiraz University of Medical Sciences, SHIRAZ, IRAN

E-mail: jaafariz@sums.ac.ir Phone: +987116263194 
recognized as cav-1(12). Among caveolin proteins, cav-1 is highly expressed in epithelial cells including keratinocytes, salivary glands and respiratory tract epithelium, as well as, osteoblasts, endothelial cells and skeletal muscles $(13,14)$. It is explained that some signaling molecules are related to the caveolin-scaffolding domain (CSD) (15) and some roles are determined for cav-1 including prevention of cells cycle progression via saving the cell cycle in G0/G1 stage, (7) cell transformation, programming cell death by activating protein kinase $\mathrm{B}(\mathrm{PKB})$ pathway (16) and acting as an oncogene or tumor suppressor gene based on the tumor type and stage (15). Also, it is shown that cav-1 can delay tumor metastasis by decreasing of matrix metalloproteinases (MMP) secretion (15).

Schwab et al. (17) reported cav-1 expression in epithelial and mesenchymal cells of tooth germ in various stages of development. That study determined that cav-1 could participate in odontogenesis (17). Since this protein is a target of treatment in some tumors, evaluation of its function in any specific pathologic lesion is suggested (15). To the best of our knowledge, there is no research about cav-1 expression in odontogenic cysts and ameloblastomas and also regarding its importance as a diagnostic or prognostic marker in lesions originating from odontogenic epithelium. This study aimed to evaluate cav-1 expression in a group of odontogenic cysts and tumors with higher prevalence and with rather similar histopathological features, and hence to investigate its possible role as a diagnostic or prognostic marker.

\section{MATERIALS and METHODS}

In this cross-sectional and analytical study, we analyzed 34 cases of ameloblastomas (14 solid and 20 unicystic types), 18 dentigerous cysts, 18 odontogenic keratocysts (also known as parakeratotic type odontogenic keratocyst and keratocystic odontogenic tumor), 3 orthokeratinized odontogenic cysts and 2 calcifying odontogenic cysts (COC). The subjects were provided from the archive of the oral and maxillofacial pathology department from 1995 to 2012. All samples had definitive diagnosis and adequate epithelial component.

Formalin-fixed and paraffin-embedded blocks were cut with $4 \mu \mathrm{m}$ thickness for immunohistochemical staining, using the Envision Labeled Peroxidase System (DAKO, Carpentaria, CA, USA). Sections were deparaffinized and rehydrated, and then washed with distilled water. Antigen retrieval was performed for 20 minutes. Then, the sections were incubated with anti-caveolin-1 polyclonal rabbit antibody (1:200, Novocastra, Newcastle, UK) for 60 minutes. The chromogen solution was 3, 3 di- aminobenzidine (DAB liquid). Positive control was provided from colon tissue (18). Endothelial cells were used as internal positive control (19). Negative control sections were provided by replacing the primary antibody with PBS solution. Brown staining of the cell membrane, cytoplasm or both, was considered as positive. All the samples were classified into three groups: negative (staining $\leq 5 \%)$, focally positive $(6 \%<$ staining $\leq$ $50 \%$ ) and extensive positive (staining $>51 \%$ ). The staining was estimated in the basal cell layer of cystic lesions and peripheral cells of ameloblastic nests.

Data were analyzed using SPSS version 11 . We used the Chisquare test and Monte-Carlo method for statistical analysis. Study groups with less than 10 cases were not evaluated in the statistical analysis. $\mathrm{P}$ values of less than 0.05 were considered as significant.

\section{RESULTS}

Expression of cav-1 was found in $88.7 \%$ of all selected samples. Table I shows the cav-1 expression in all groups with details. All the cystic lesions were positive for cav1. Membranous and cytoplasmic immunoreactivity was observed throughout the basal cell layer of all cysts (Figures $1 \mathrm{~A}, \mathrm{~B}, 2 \mathrm{~A}, \mathrm{~B}, \mathrm{C})$. This pattern was similar in all odontogenic cysts. A limited number of odontogenic cysts in each group showed slight staining in superficial cells. Also, one out of two COCs showed cav-1 expression in superficial stellate reticulum-like cells.

We observed cav-1 expression in $65 \%$ of unicystic and $55 \%$ of solid ameloblastoma. In the luminal unicystic ameloblastoma, the basal ameloblast-like cells were positive. Superficial epithelial cells were stained in a few cases. Mural and solid ameloblastomas showed immunoreactions in the peripheral ameloblast-like cells of the tumoral nests

Table I: Caveolin-1 expression in all study groups

\begin{tabular}{|l|c|c|c|}
\hline & Negative & $\begin{array}{c}\text { Focally } \\
\text { positive }\end{array}$ & $\begin{array}{c}\text { Extensive } \\
\text { positive }\end{array}$ \\
\hline Study groups (n) & $0-5 \%$ & $6-50 \%$ & $>50 \%$ \\
\hline Ameloblastoma(14) & $35 \%$ & $10 \%$ & $55 \%$ \\
\hline UA (20) & $44.9 \%$ & $7.1 \%$ & $48 \%$ \\
\hline $\begin{array}{l}\text { Odontogenic } \\
\text { keratocyst(18) }\end{array}$ & $0 \%$ & $0 \%$ & $100 \%$ \\
\hline Dentigerous cyst(18) & $0 \%$ & $0 \%$ & $100 \%$ \\
\hline $\begin{array}{l}\text { Orthokeratinized OC } \\
(3)\end{array}$ & $0 \%$ & $0 \%$ & $100 \%$ \\
\hline COC(2) & $0 \%$ & $0 \%$ & $100 \%$ \\
\hline
\end{tabular}

UA: Unicystic ameloblastoma, OC: odontogenic cyst, COC: Calcifying Odontogenic Cyst 

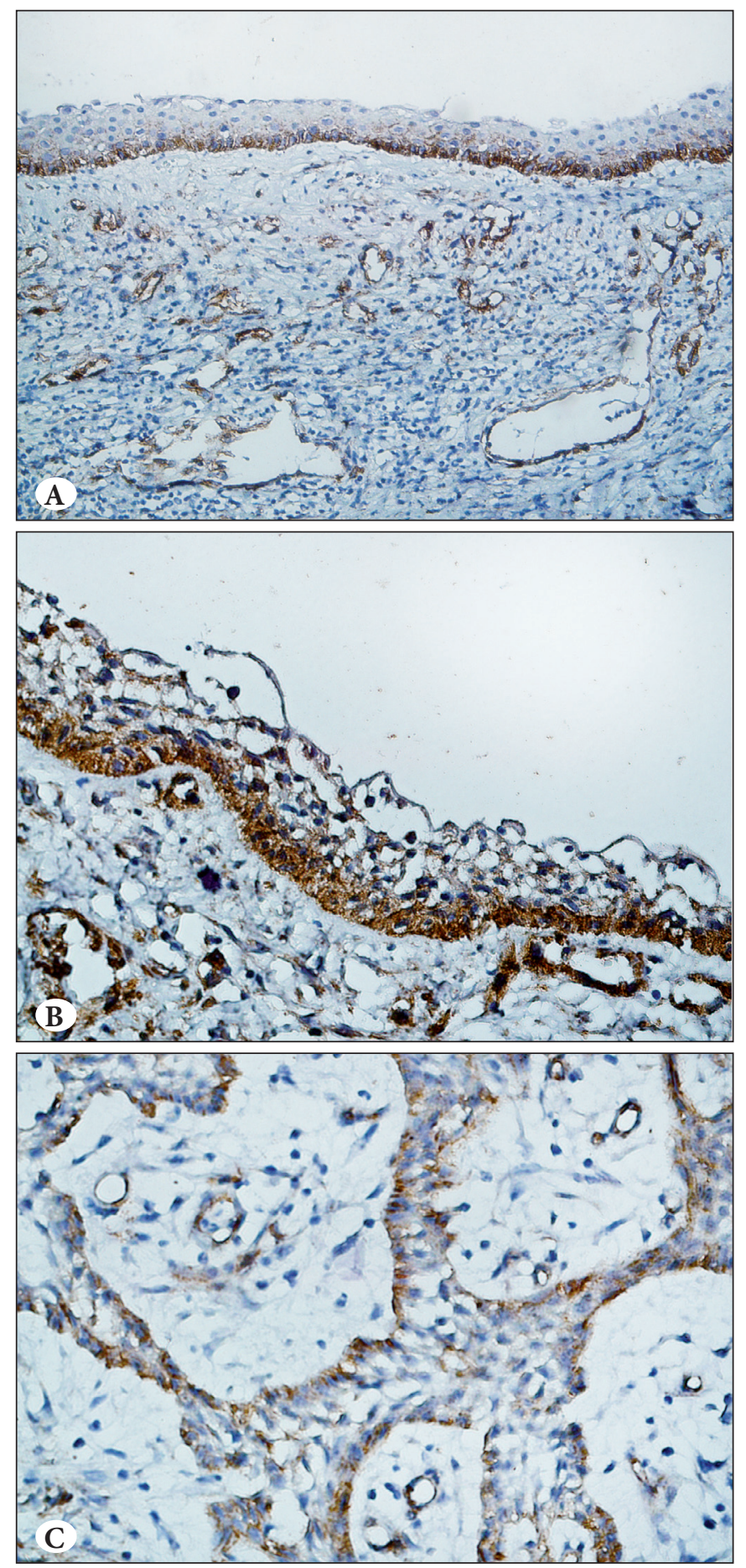

Figure 1: Immunohistochemical staining of cav-1 in A) Dentigerous cyst (x200), B) Unicystic ameloblastoma (x200). C) Ameloblastoma (x400).

(Figure 1B,C). The central stellate reticulum-like cells were stained in some cases, although most of the cases did not show immunoreaction in the central portion of the tumoral nests. The area of squamous metaplasia also was not stained. Cav-1 expression was also membranous and
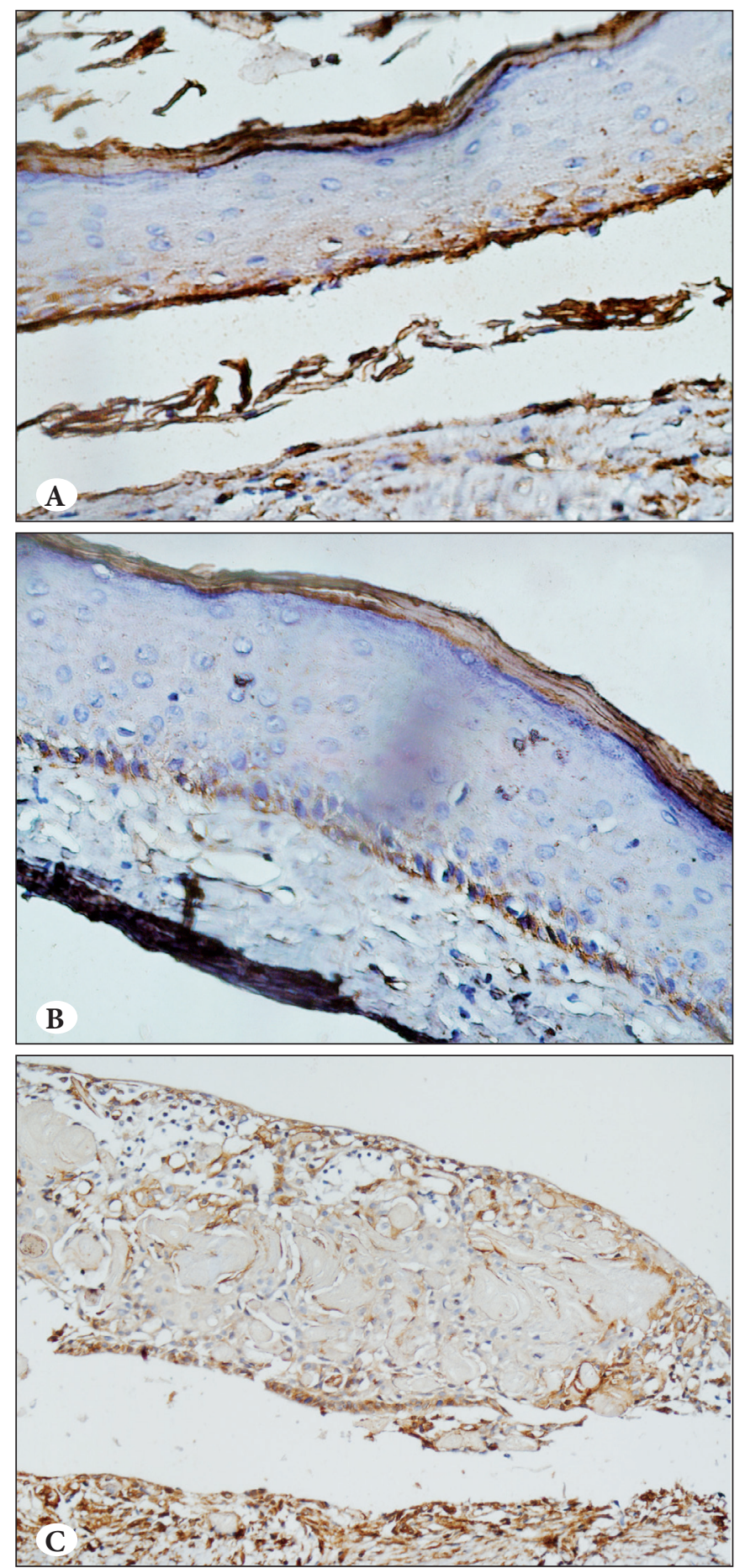

Figure 2: Immunohistochemical staining of cav-1 in A) Odontogenic keratocyst (x200). B) Orthokeratinized odontogenic cyst (x200). C) Calcifying odontogenic cyst (x200).

cytoplasmic in ameloblastomas. Chi-square test showed significant difference between ameloblastoma (unicystic and solid) and other odontogenic lesions regarding cav-1 expression. However, the other study groups were similar regarding the marker expression ( $\mathrm{P}$-value $<0.05$ ). 


\section{DISCUSSION}

In the present study, we evaluated the expression of cav1 in a group of odontogenic cysts and tumors for the first time. Our results showed that all odontogenic cystic lesions extensively expressed the marker in the basal cell layer, without significant difference. However, both solid unicystic ameloblastomas revealed immunoreactivity to a smaller degree and more focally. These findings might suggest that cav- 1 could be a tumor suppressor in odontogenic tumors. It has been stated that cav-1 plays opposing roles in different tumors (11). Previous studies have shown a tumor suppressor function in sarcomas and ovarian carcinomas $(20,21)$. Reduced cav-1 expression was also described in mucoepidermoid carcinoma of salivary glands, colon and breast cancers as well as lung carcinoma cell lines (9). It was revealed that hypermethylation of cav-1 gene promoter caused reduced protein expression in these cancers (22).

However, some studies have demonstrated an oncogenic role for cav-1 in some tumors. Its upregulation was observed in primary and metastatic prostate cancer (9). Also, increasing expression of the marker was found from normal oral epithelium to dysplastic and neoplastic epithelial tissue (squamous cell carcinoma) (9). Bau et al. (23) demonstrated that polymorphism of the cav-1 gene in some genotypex was associated with oral cancer susceptibility. They found the expression of cav-1 in the basal and parabasal layers. The expression of cav-1 in our samples was also observed in the basal cell layer. Despite the fact that the immunoreaction was mainly found in the basal cells, it seems that this marker is not related to proliferation activity in our samples. Various studies have evaluated the expression of proliferation markers (such as Ki-67) in odontogenic cysts and tumors and reported that ameloblastomas had higher proliferative activity in comparison with other odontogenic cysts (24). In our study the tumoral lesions that have higher proliferation rate, revealed similar or lower expression of cav-1, compared to the other lesions. It has also been shown that odontogenic keratocysts had higher expression of proliferation markers in comparison with other cystic lesions, and that the parabasal cell layer of this lesion revealed a higher expression rate than the basal layer (25). However, our study showed different results for cav1 expression. It was therefore concluded that this protein had no role in proliferative activity in odontogenic cysts and tumors. Other studies suggested a possible negative regulation of proliferation due to high expression of cav1 in terminally differentiated cells (26-28). However, we found this marker in less differentiated cells in the cysts and tumors (basal cells, ameloblast-like and some stellate reticulum- like cells) and not in differentiated superficial cells of odontogenic cysts and squamous change in ameloblastoma.

Our samples revealed both cytoplasmic and membranous immunoexpression. The caveolin proteins have two main domains (scaffolding and membranous) and they are in relation with different molecules such as C- Src and Cirb7 , resulting in different roles in various pathologic lesions (22).

Expression of cav-1 has been shown previously in enamel organ, especially inner enamel epithelium and ameloblast cells of developing tooth germ (17). It was also demonstrated that cav-1 participated in cell transformation and differentiation (15). So, this study hypothesizes that cav-1 may be a useful marker for differential diagnosis of odontogenic lesions. Odontogenic keratocyst and orthokeratinized odontogenic cyst have histopathologic similarities. Also, differentiating unicystic ameloblastoma from dentigerous cyst and COC may be difficult. According to our results, the similar cystic lesions expressed the marker with the same pattern. All cases of keratinized odontogenic cysts and dentigerous cyst showed extensive immunoreaction in basal cell layer. Although, we found cav-1 expression in the superficial cells of one out of two COCs and a few cases of unicystic ameloblastoma, the limited number of the cases necessitates the further research for evaluation of usefulness of this marker for differentiating of these lesions. Unicystic ameloblastoma and solid ameloblastoma also showed similar expression. Therefore, this marker could not help in distinguishing these lesions from each other. However, due to significant difference between unicystic ameloblastomas and dentigerous cyst, absence of cav-1 expression supports the unicystic ameloblastoma diagnosis. Moreover, this result could be confirmed by future studies with larger sample size. Also, it suggested that other odontogenic tumors should be examined in comparison with ameloblastomas for evaluation of usefulness of this marker for differential diagnosis.

In the present study, we observed diminished expression of cav-1 in ameloblastomas that have a locally aggressive nature when compared to the other study groups. Previous studies revealed the diverse role for cav-1 in different lesions and since cav- 1 might be a target of treatment in various tumors, it was suggested that this role should be explained in any pathogenic condition (15). We conclude that this protein may be in association with increased invasiveness of ameloblastoma. A study has shown co-localized expression of cav-1 with extracellular matrix metalloproteinase 
inducer (EMMPRIN) in developing tooth germ and has concluded that cav-1 regulates the EMMPRIN-induced expression of MMPs (29). It was suggested that EMMPRIN induces the MPP dependent degradation of extracellular matrix during tumor progression (29). Cav-1 on the cell surface decreases glycosylasion of EMMPRIN, resulting in diminished expression of MMPS that participates in tumoral invasion (17). Also, it has been shown that down regulation of cav-1 decreases the expression of E-cadherin and increases the activation of $\beta$-catenin, both resulting in enhanced invasiveness of neoplasms (15).

In conclusion, our results showed cav-1 expression in all odontogenic cysts and $58 \%$ of ameloblastomas. This protein could function as a tumor suppressor in odontogenic lesions and may decrease their aggressiveness. It is suggested that these results be evaluated in further studies with gene analysis. The absence of its expression might provide a diagnostic aid for distinguishing unicystic ameloblastomas from other odontogenic cysts.

\section{ACKNOWLEDGEMENT}

The authors would like to thank Dr Sh. Hamedani (DDS, MSc) for helping with the English and editorial assistance in the manuscript and Dr M. Vossoughi from the Dental Research Development Centre, for the statistical analysis. This manuscript is related to post- graduate thesis of Dr. Maryam Asadzadeh (Shiraz University of Medical Science, Shiraz, Iran).

\section{CONFLICT OF INTEREST}

Vice-chancellery of Shiraz University of Medical Sciences supported the research (Grant\#91-01-03-5394).

\section{REFERENCES}

1. Altini M, Coleman H, Doglioni C, Favia G, Maiorano E. Calretinin expression in ameloblastomas. Histopathology. 2000; $37: 27-32$

2. Cairns L, Naidu A, Robinson CM, Sloan P, Wright JM, Hunter KD. CD56 (NCAM) expression in ameloblastomas and other odontogenic lesions. Histopathology. 2010;57:544-8.

3. Er N, Dağdeviren A, Taşman F, Zeybek D. Cell adhesion molecule and neurothelin expression in human ameloblastoma. J Oral Maxillogac Surg. 2001;23:900-3.

4. Kusafuka K, Hirobe K, Wato M, Tanaka A, Nakajima T. CD56 expression is associated with neuroectodermal differentiation in ameloblastomas: An immunohistochemical evaluation in comparison with odontogenic cystic lesions. Med Mol Morphol. 2011;44:79-85.

5. Shigeo K, Eisako I, Akira Y, Yoshinobu E, Norihiko O. Immunohistochemical characteristics of odontogenic carcinomas: Their use in diagnosting and elucidating histogenesis. Oral Medicine and Pathology. 2008;13:55-63.
6. Jaafari -Ashkavandi Z, Dehghani Najvani A, Andishe Tadbir A, Pardis S, Ranjbar MA, Ashraf MJ. MCM3 as a novel diagnostic marker in benign and malignant salivary gland tumors. Asian Pacific J Cancer Prev. 2013;14:3479-82.

7. Keisuke N, Hitoshi N, Hidetsugu T, Mehmet G, Naoki K, Chong $\mathrm{H}$, Toshiyuki $\mathrm{K}$. Immunohistochemical characteristics of odontogenic neoplasms and their physiological counterparts. Journal of Hard Tissue Biology. 2008;17:79-90

8. Mistry D, Altini M, Coleman HG, Ali H, Maiorano E. The spatial and temporal expression of calretinin in developing rat molars (Rattus norvegicus). Arch Oral Biol. 2001;46:973-81.

9. Hung KF, Lin SC, Liu CJ, Chang CS, Chang KW, Kao SY. The biphasic differential expression of the cellular membrane protein, caveolin-1, in oral carcinogenesis. J Oral Pathol Med. 2003;32:461-7.

10. Lajoie P, Nabi RI. Lipid rafts, caveolae, and their endocytosis. Int Rev Cell Mol Biol. 2010;282:135-63.

11. Liu P, Rudick M, Anderson RG. Multiple functions of caveolin-1. J Biol Chem. 2002;277:41295-8.

12. Roberts AB, Wakefield LM. The two faces of transforming growth factor beta in carcinogenesis. Proc Natl Acad Sci USA. 2003;100: 8621-3.

13. Liu P, Li WP, Machleidt T, Anderson RG. Identification of caveolin-1 in lipoprotein particles secreted by exocrine cells Cell Biol. 1999;1:369-75.

14. Li WP, Liu P, Pilcher BK, Anderson RG. Cell-specific targeting of caveolin-1 to caveolae, secretory vesicles, cytoplasm or mitochondria. J Cell Sci. 2001;114:1397-1408.

15. Williams TM, Lisanti MP. Caveolin-1 in oncogenic transformation, cancer and metastasis. Am J Phisiol. 2005;288: C494-506.

16. Li L, Ren CH, Tahir S, Ren C, Thompson TC. Caveolin-1 maintains activated Akt in prostate cancer cells through scaffolding domain binding site interactions with and inhibition of serine/threonine protein phosphatases PP1 and PP2A. Mol Cell Biol. 2003;23: 9389-404.

17. Schwab W, Harada H, Goetz W, Nowicki M, Witt M, Kasper M, Barth K. Immunocytochemical and biochemical detection of EMMPRIN in the rat tooth germ: Differentiation-dependent co-expression with MMPs and co-localization with caveolin-1 in membrane rafts of dental epithelial cells. Histochem Cell Biol. 2007;128:195-203.

18. Bender FC, Reymond MA, Bron C, Quest AF. Caveolin-1 levels are down-regulated in human colon tumors, and ectopic expression of caveolin-1 in colon carcinoma cell lines reduces cell tumorigenicity. Cancer Res. 2000;60:5870-78.

19. Chidlow JH Jr1, Greer JJ, Anthoni C, Bernatchez P, FernandezHernando C, Bruce M, Abdelbaqi M, Shukla D, Granger DN, Sessa WC, Kevil CG. Endothelial caveolin-1 regulates pathologic angiogenesis in a mouse model of colitis. Gastroenterology. 2009;136:575-84.

20. Weichen K, Diatchenko L, Agoulnik A, Scharff KM, Schober H, Arlt K, Zhumabayeva B, Siebert PD, Dietel M, Schäfer R, Sers C. Caveolin-1 down-regulated in human ovarian carcinoma and acts as a candidate tumor suppressor gene. Am J Pathol. $2001 ; 158: 1635-43$ 
21. Wiechen K, Sers C, Agoulnik A, Arlt K, Dietel M, Schlag PM, Schneider U. Down-regulation of caveolin-1, a candidate tumor suppressor gene, in sarcomas. Am J Pathol. 2001;158:833-9.

22. Cohen AW, Hnasko R, Schubert W, Lisanti MP. Role of caveolae and caveolins in health and disease. Physiol Rev. 2004;84:134179.

23. Bau DT, Tsai MH, Tsou YA, Wang CH, Tsai CW, Sun SS, Hua $\mathrm{CH}$, Shyue SK, Tsai RY. The association of Caveolin-1 genotypes with oral cancer susceptibility in Taiwan. Ann Surg Oncol. 2011;18:1431-8.

24. Amaral FR, Mateus GC, Bonisson LA, de Andrade BA, Mesquita RA, Horta MC, Marigo Hde A. Cell proliferation and apoptosis in ameloblastomas and keratocystic odontogenic tumors. Braz Dent J. 2012;23: 91-6.

25. Gadbail AR, Patil R, Chaudhary M. Co-expression of Ki-67 and p53 protein in ameloblastoma and keratocystic odontogenic tumor. Acta Odontol Scand. 2012;70:529-35.
26. Galbiati F, Volonte D, Liu J, Capozza F, Frank PG, Zhu L, Pestell RG, Lisanti MP. Caveolin-1 expression negatively regulates cell cycle progression by inducing G0/G1 arrest via a p53/p21 (WAF1/ Cip1)-dependent mechanism. Mol Biol Cell. 2001;12:2229-44.

27. Lee SW, Reimer C, Oh P, Campbell DB, Schnitzer JE. Tumor cell growth inhibition by caveolin re-expression in human breast cancer cells. Oncogene. 1998;16:1391-7.

28. Scheel J, Srinivasan J, Honnert U, Henske A, Kurzchalia T. Involvement of caveolin-1 in meiotic cell-cycle progression in Caenorhabditiselegans. Nat Cell Biol. 1999:127-9.

29. Kumamoto H, Ooya K. Immunohistochemical detection of MT1MMP, RECK, and EMMPRIN in ameloblastic tumors. J Oral Pathol Med. 2006;35:345-51. 